\title{
An Algorithm of Decomposing the Trend and Cyclical Components of FDI Inflows: the Case of Ukraine
}

http://doi.org/ 10.21272/fmir.4(3).95-101.2020

Bogdan A. Moskalenko, ORCID: $\underline{\text { https://orcid.org/0000-0003-3972-1705 }}$

Joint stock company "ProCredit Bank", Business Client Advisor, Kyiv, Ukraine

Pavlin Mitev, ORCID: https://orcid.org/0000-0001-5798-4192

Joint stock company "Raiffeisenbank EAD”, Credit Risk Policy Manager, Bulgaria

\begin{abstract}
The article summarizes the arguments within the scientific challenge on improving approaches to country investment potential evaluation. The main objective of the research is to systematize the existing statistical methods of decomposing macroeconomic time series into growth (trend) and cyclical components. Systematization of theoretical and methodological materials on solving the problem of decomposing the trend and cyclical components of time data series showed that the use of filtering series of economic dynamics based on the Hodrick-Prescott filter allows identifying long-term growth trends or recessions. The relevance of solving this problem is that the country investment potential evaluation is often based on investigating the impact of foreign direct investment's determinants in a domestic economy while ignoring cyclical macroeconomic processes within and outside the country, on which those determinants often have not responded yet or reacted late. The methodical tools of the research are carried out in the following logical sequence: systematization of existing statistical methods for trend component decomposing; analysis of data that will be used in the decomposition process and in further country investment potential evaluation; application of the Hodrick-Prescott filter and trend component decomposing in foreign direct investment net inflows dynamics into the economy of Ukraine. The Research methods combine in following dimensions: comparative analysis, regression analysis and univariate methodology of time series decomposing. The period from 1999 to 2019 was chosen as the research period. The object of the research is foreign direct investment net inflows into the economy of Ukraine, as they are the determining element within the country investment potential evaluation process. The article presents the results of empirical analysis, which showed that the decomposing a trend and cyclical components of foreign direct investment inflows can improve the quality of investment potential evaluation, considering the impact of current economic cycle phase. The results of the research can be useful for a more accurate investment potential evaluation on the macroeconomic level and forecasting foreign direct investment inflows for the following time periods.
\end{abstract}

Keywords: business cycle synchronization; country investment potential; foreign direct investment; HodrickPrescott filter; national economy.

JEL Classification: E22, E 29, E 44, E 60, G31.

This work is licensed under a Creative Commons Attribution 4.0 International License

Cite as: Moskalenko, B. A., Mitev, P. (2020). An Algorithm of Decomposing the Trend and Cyclical Components of FDI Inflows: the Case of Ukraine. Financial Markets, Institutions and Risks, 4(3), 95-101. http://doi.org/ 10.21272/fmir.4(3).95-101.2020.

(C) The Author, 2020. This article is published with open access at Sumy State University.

\section{Introduction}

Potential foreign direct investment (FDI) inflows could be defined as the maximum level of FDI inflows which is affordable without tensions in the economy: creating by government artificial conditions for FDI inflows via fiscal policy tools, more precisely without fiscal dumping. The FDI inflows gap is the difference between current level of FDI inflows and its considered (potential) level. The potential FDI inflow is a function of macroeconomic indicators, and the FDI inflow gap is an insufficiency of FDI supply on national economy investment projects. As follows, positive FDI inflow gap means FDI inflows above potential expectations, and negative one indicates insufficient utilization of country investment attractiveness.

In current studies, potential output and output gap concepts are connected mostly to GDP and GDP-related 
indexes. Cyclical component of GDP dynamic is highly correlated to that of FDI one in the scale of same national economy, which could be proved by comparison respective graphs on one chart.

Country investment potential estimation could provide with results which are significant for understanding current situation on international investment market and highlight the most influential determinants of FDI inflows in analyzed national economy. That information is useful for government institutions, respective policy makers, and businesses that are supposed to make investment decisions.

Within this work, the authors aim to analyze and estimate the differences between the level of actually received FDI inflows and that of potential ones at a particular point in time, considering cyclical fluctuations of economic activity.

\section{Literature Review}

Within few decades of active research literature related to investment potential estimation on macroeconomic level has evolved over time. Despite this, recent ideas from around the globe are attempting to explain this phenomenon using a strong scientific theoretical foundation and statistical data. Discovering the problems of investment attractiveness and investment potential of national economy evaluation, several scientific achievements of domestic and foreign scientists were analyzed.

The problem of estimation trend and cyclical components within time series data begins from Okun (1962) who defined potential gross domestic product as the answer to the question: "How much output can the economy produce under conditions of full employment?" (Okun, 1962). In support of that statement, De Masi concludes, that potential GDP is the maximum output which an economy is able to provide without generating a significant inflation growth (De Masi, 1997).

In many cases, the analysis of potential output and output gap is regarded as the starting point for studying business cycles (Ladiray et al. 2003). Several authors (Orphanides et al., 2002, Nelson et al., 2003, Dimitz, 2001) have structured and developed theoretical principles and methods of output gap estimation.

Group of scientists (Melnyk et al., 2014) have discussed an impact of FDI inflows on GDP dynamic within Ukrainian economy. In developing of that, Kubatko analyses the impact of macroeconomic fluctuations in Ukraine on socio-economic relations with EU institutions (Kubatko and Pimonenko, 2015).

Methodologies to determine potential output estimation related to economic and business cycles can be split into statistical and structural group of approaches (Anderton et al., 2014). Statistical methods are related to an idea of extracting the unobserved trend from the observed time series data. The result will contain a trend and a cyclical component. Structural approaches are based on a model of the supply side of the economy. Accordingly to that, evaluation is motivated mostly by an attempt to account the way in which an economy grows. Some statistical approaches extract the trend from just one variable. Among them probably the most well-known is Hodrick-Prescott filter (Hodrick and Prescott, 1997).

Another statistical estimation could be performing by Baxter-King filter (Baxter and King, 1999), which separates the fluctuations that are longer-term (low frequency), from shorter-term (high frequency). Multivariate approaches extract the trend of the output series by using the information from other series, such as gross domestic product, inflation, currency exchange etc. Among which it is noticeable a two-step algorithm for the projection of an unobserved variable by means of a number of other, observed, variables; for a technical exposition of multivariate (Cotis et al., 2008).

Among structural approaches the most frequent ones are the Cobb-Douglas method and the constant elasticity of substitution which help explain the key economic forces influencing output and growth developments in the medium term (D'Auria et al, 2010).

Accordingly to the topic and purposes of this research, the analysis will be conducted based on statistical approaches, which will be explained within the following chapter. 


\section{Theoretical Framework for potential and cyclical components estimation}

Univariate methods estimate the data in time series itself within the decomposing process. Most of in other words, they calculate information coming from observed output as an expression of potential output (Bjørnland et al., 2005).

Multivariate methods make use a number of variables for decomposing time series into trend and cyclical components. Among those variables could be used GDP, ongoing or outgoing FDI, inflation, unemployment etc. Some of most used methods are briefly explained in Table 1.

Table 1. Methods for estimation potential and cyclical components within time series

\begin{tabular}{|c|c|}
\hline \multicolumn{2}{|r|}{ Univariate methods } \\
\hline $\begin{array}{l}\text { Deterministic de- } \\
\text { trending }\end{array}$ & $\begin{array}{l}\text { estimates the potential output as a deterministic (linear or quadratic) trend, as it follows, the gain of this } \\
\text { filter is characterized by the fact that it removes only partially the components whose frequency is close } \\
\text { to zero (Ladiray et al., 2003) }\end{array}$ \\
\hline $\begin{array}{l}\text { First difference de- } \\
\text { trending }\end{array}$ & $\begin{array}{l}\text { removes the trend component from the series and gives an estimate of the transitory component. Received } \\
\text { auto-correlation function is characterized by some negative spurious correlation at lag one which can } \\
\text { provide with some relevant bias in calculated cyclical component (Ladiray et al., 2003) }\end{array}$ \\
\hline Hodrick-Prescott filter & $\begin{array}{l}\text { finds the value of potential output that minimises the difference between actual output and potential } \\
\text { output while imposing constraints on the extent to which growth in potential output can vary }\end{array}$ \\
\hline Baxter and King Filter & $\begin{array}{l}\text { can make use of historical experience with regard to the duration of business cycle (by considering the } \\
\text { frequency of cyclical fluctuations) when estimating the output gap. Therefore, we can say that our } \\
\text { business cycle has the length that has historically been observed for business cycles (Badar et al., 2015) }\end{array}$ \\
\hline $\begin{array}{l}\text { Beveridge Nelson } \\
\text { decomposition }\end{array}$ & imposes restrictions on the trend and the cycle to identify the decomposition trend/cycle \\
\hline \multicolumn{2}{|r|}{ Multivariate methods } \\
\hline $\begin{array}{l}\text { Hodrick-Prescott filter } \\
\text { (MV) }\end{array}$ & $\begin{array}{l}\text { includes structural relationships such as Phillips curve, the Okun's Law and the NAIRU hypothesis, it } \\
\text { makes also possible to envisage time varying weights of smoothing parameter that reflects the change of } \\
\text { importance level in the estimation period (Chagny and Döpke, 2001) }\end{array}$ \\
\hline $\begin{array}{l}\text { Beveridge Nelson } \\
\text { decomposition }\end{array}$ & $\begin{array}{l}\text { converts time series into random walk (permanent) and transitory components. shock driving this trend } \\
\text { is supposed to be a linear combinaison of innovations of GDP and other variables which contains useful } \\
\text { information to determine long term GDP. (Murasawa, 2015) }\end{array}$ \\
\hline $\begin{array}{l}\text { Unobserved } \\
\text { component method }\end{array}$ & $\begin{array}{l}\text { makes it possible to give some indication of the uncertainty associated with the estimated output gap. } \\
\text { The quality of the estimated output gap will depend on how realistic these assumptions are (Bjornland et } \\
\text { al., 2005) }\end{array}$ \\
\hline Kalman filter & $\begin{array}{l}\text { assumes that macroeconomic data are composed of directly unobservable trend, cycle and erratic } \\
\text { components, taking into consideration that inflation and unemployment have a stable and inverse } \\
\text { relationship (Chui and Chen,2009) }\end{array}$ \\
\hline
\end{tabular}

Notes: Compiled by the author.

\section{Methodology and research methods}

Research methods combine in following dimensions: comparative analysis, regression analysis and univariate methodology of time series decomposing. There are some data limitations that are discussed below. The data processing was done via STATA 14 . The capacity of an economy to attract, and most importantly, to utilize foreign direct investments (FDI) has been disputed by scientists over last few decades. Historical data, provided by World Bank, and other institutions, proves that FDI inflows and outflows have cyclical characteristics; consequently, they are able to be measured by statistical tools and methods. In this study we assume, that FDI inflows are highly dependent on macroeconomic situation, measured by respective indexes, such as gross domestic product growth rate, unemployment rate, amount of export and import, government expenses etc. As a consequence, the dynamic of FDI inflows are influenced by economic and business cycles of a country where it belongs. It is important to emphasize, that unlike many macroeconomic indexes, potential inflow of FDI cannot be measured directly, and so ought to be estimated. Potential FDI inflow clearly differs from actual one, and, thus it would not be expected to display the same short-term cyclical movements as actual one, it will fluctuate from period to period. Those fluctuations (in potential inflows) reflect changes in the trend components. The FDI inflows gap is an economic measure of the difference between the actual amount of FDI inflows into an economy and its potential to attract those resources. Investment potential is the maximum amount of FDI an economy can absorb when it is most efficient that is, at full capacity. The Hodrick and Prescott filter is known and commonly used statistical method for evaluation of potential component of time series. This filter is a smoothing procedure that extracts a non-linear trend component from observed output by minimizing a weighted average of the variability in the trend and its deviations from actual time series data 
(Almeida and Felix, 2006). Let us assume that some time series data consists of the growth (trend) and cyclical (transitory) component. Related to our study, FDI inflows data could be presumed as the following formula:

$y_{t}=\tau_{t}+c_{t}$,

where $y_{t}$ is FDI inflows at year $\mathrm{t}, \tau_{t}-$ trend component of FDI inflows, $c_{t}-$ cyclical component of FDI inflows.

Trend component $\tau_{t}$ could be extracted from time series data $y_{t}$ within solving the following equation:

$\min _{\tau_{t}} \sum_{t=1}^{T}\left(\left(y_{t}-\tau_{t}\right)^{2}+\lambda\left(\left(\tau_{t+1}-\tau_{t}\right)-\left(\tau_{t}-\tau_{t-1}\right)\right)^{2}\right)$,

where $y_{t}$-actual data of FDI inflows at year $\mathrm{t}, \lambda$ - smoothing parameter, $\tau_{t}-$ trend component of FDI inflows, $\mathrm{T}$ - number of observations.

The role of the smoothing parameter $\lambda$ is crucially important for estimation using H-P filter. By increasing the value of $\lambda$ the result obtains smoother estimates of the trend component $\tau_{t}$, and more volatile estimates of the cyclical component $c_{t}$. Accordingly, to (Hodrick and Prescott, 1980) propose recommended values for $\lambda$ are:

$\lambda=100$ for annual data;

$\lambda=1600$ for quarterly data;

$\lambda=14400$ for monthly data.

The data source is statistic information gathered and published by World Bank. Ukrainian macroeconomic statistics are available since 1991, but it should be mentioned that in $90^{\text {th }}$ Ukrainian economy and social-politic situation as whole was highly vulnerable. Considering that, in order avoid widening the scale of errors, in this study data was used within the period from 1999 to 2019. Some of statistical data ought to be represented as its logarithmic interpretation - in order to achieve needed visual effect.

\section{Results}

It is assumed based on mentioned previously, macroeconomic indexes such as FDI inflows and GDP per capita within same market economy, ceteris paribus, are reasonably correlated. Dynamics of FDI net inflows (BoP, current USD), and GDP per capita (current USD) in Ukrainian economy within period from 1999 till 2018 is shown in Figures 1.

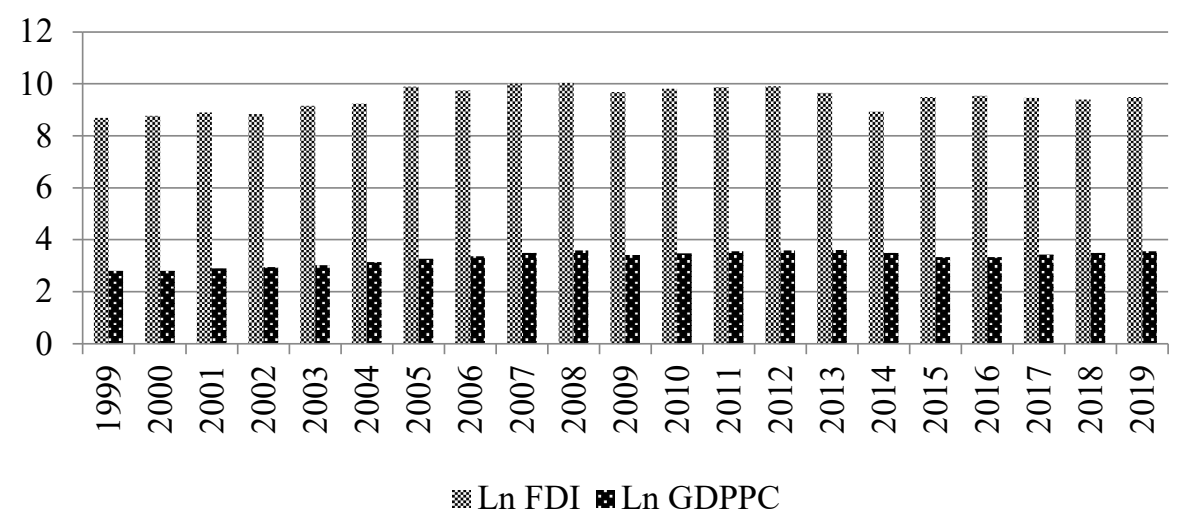

Figure 1. GDP per capita and FDI net inflows dynamic in Ukrainian economy, USD

Sources: WorldBank data, Ukraine, 1999-2019, annual report (2020).

Exploring the data shown in Figure1, it is noticeable some congruence between FDI net inflows and GDP per capita. Although, the graphs show four detached periods:

1. 1999-2004 - fast-growing development that was pushed massive privatization processes, start of market economy reforms, and favourable situation on international markets;

2. 2005-2008 - privatization processes and favourable situation on international markets were facing political instability, slowdown of reforming;

3. 2009-2013 - consequences of world economic crisis, post-crisis growth was stopped by political crisis 
and following pre-scheduled change of government;

4. 2014-2019 - external forced occupation part of country`s territory and following war action, significant drop of economic activity.

Table 2 shows the results of correlation-regression analysis of the impact of FDI net inflows in Ukraine on GDP per capita for 1999 - 2019. The calculations will be performed using econometric software STATA 14.

Table 2. Regression analysis of the impact of FDI net inflows on GDP per capita

\begin{tabular}{|l|c|c|c|c|c|c|}
\hline \multirow{2}{*}{ Source } & \multirow{2}{*}{$\mathrm{SS}$} & \multirow{2}{*}{$\mathrm{df}$} & \multirow{2}{*}{$\mathrm{MS}$} & Number of obs & $=$ & 20 \\
\cline { 5 - 7 } & & & & $\mathrm{F}(1,18)$ & $=$ & 34.121 \\
\hline Model & 0.907373 & 1 & 0.907373001 & Prob $>$ F & $=$ & 0.0000 \\
\hline Residual & 0.478668 & 18 & 0.026592685 & R-squared & $=$ & 0.6546 \\
\hline \multirow{2}{*}{ Total } & \multirow{2}{*}{1.386041} & \multirow{2}{*}{19} & & Adj R-squared & $=$ & 0.6354 \\
\cline { 5 - 7 } & & & Root MSE & $=$ & 0.1631 \\
\hline ln_GDPPC & Coef. & Std. Err. & $\mathrm{t}$ & $\mathrm{P}>|\mathrm{t}|$ & {$[95 \%$ Conf. } & Interval] \\
\hline ln_FDI & 1.5808194 & 0.296486 & 5.33 & 0.000 & 0,95793 & 2,20371 \\
\hline cons & 0.4983038 & 0.085307 & 5.84 & 0.000 & 0,67752 & 0,31908 \\
\hline
\end{tabular}

Sources: developed by the authors

Regression analysis has shown that $\mathrm{R}^{2}=0.65$ which means a significant and positive impact of FDI net inflows on GDP per capita. Although, P-value $(\mathrm{P}>|\mathrm{t}|)$ is less than 0.05 , which indicates high level of statistical significance of whole model.

Following the results shown in Table 2, the change in GDP growth by per capita in Ukraine from FDI inflows since 1999 to 2019 can be characterized by a regression model:

$Y=0.4983+1.5808 F D I$,

where $\mathrm{Y}-\ln ($ GDP per capita, USD), FDI - $\ln$ (FDI net inflows, USD).

Following the interpretation mentioned in the last chapter, and taking into consideration high dependency within FDI and GDP dynamics, the next step within investment potential evaluation process could be performed by extraction of trend component of FDI inflows data series (see Figure 2).

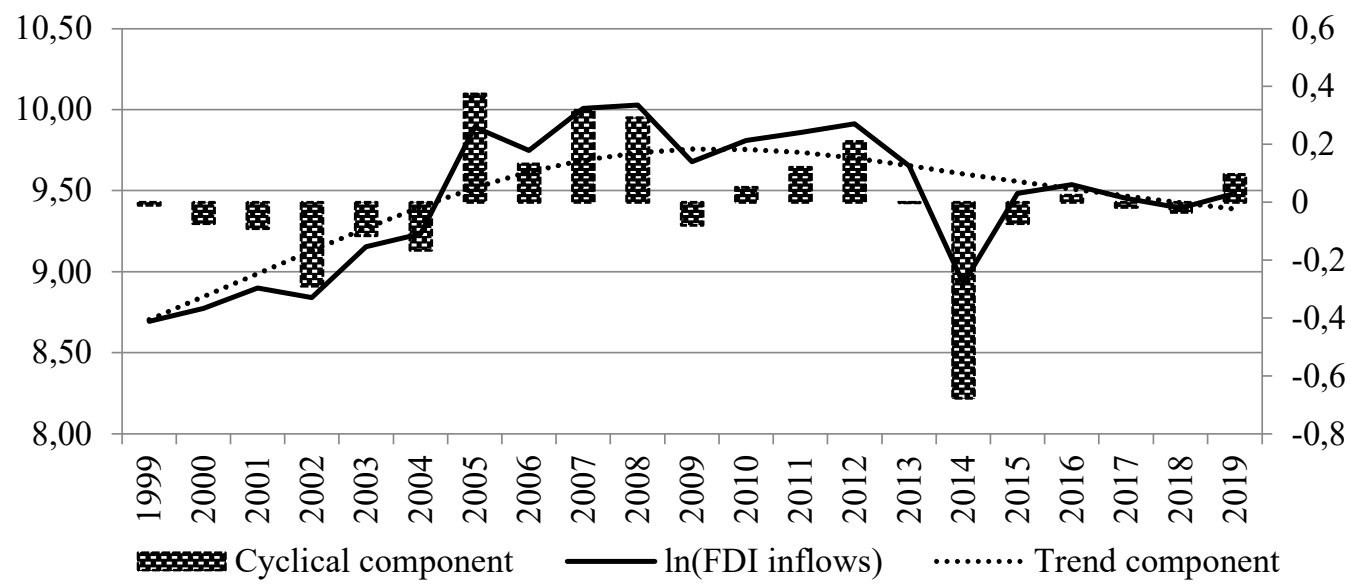

Figure 2. Fluctuation of cyclical and trend components of FDI Inflows in Ukrainian economy

Source: calculated by the authors on the basis of WorldBank data (2020).

Results of evaluation of potential component of FDI inflows time series using the Hodrick-Prescott filter. In accordance to the statement, that fluctuations are a deviation from the long-term dynamics of development environmental and economic indicators, the issue of impact research is important fluctuations on real data in time series. Thus, as it is shown in Figure 2, cyclical component fluctuation relates to previously mentioned detached periods. Net FDI inflows in Ukrainian economy are dropping since 2009 despite all the efforts done by different ruling governments within this period. 
Table 3. Decomposed structure of FDI net inflows in Ukrainian economy in 2013-2019*

\begin{tabular}{|l|c|c|c|c|c|c|c|}
\hline Indexes & 2013 & 2014 & 2015 & 2016 & 2017 & 2018 & 2019 \\
\hline $\ln$ (FDI inflows) & 9,6541 & 8,9279 & 9,4843 & 9,5367 & 9,4513 & 9,3938 & 9,4833 \\
\hline Trend component & 9,655 & 9,6045 & 9,5568 & 9,5118 & 9,4688 & 9,4275 & 9,3871 \\
\hline Cyclical component & $-0,0009$ & $-0,6767$ & $-0,0725$ & 0,0249 & $-0,0175$ & $-0,0337$ & 0,0962 \\
\hline
\end{tabular}

Data is represented as $\ln$ values.

Source: calculated by the authors on the basis of WorldBank data (2020).

The recent dynamic of FDI net inflows (see Table 3) shows changing of cyclical component from negative to positive value. That could be assumed as a start of new FDI inflows growing cycle. Although, coherence of FDI inflows fluctuations is relative to fluctuations in economic development mean that the phases of growth and decline have coincide in the dynamics of the cyclical component of these indicators. Results performed by H-P filter provide trend component of FDI inflows as of 2019 amounted to 9.4833. This is the basic for following country investment attractiveness evaluation using known technics of estimation the impact of determinants of FDI inflows.

\section{Conclusions, Discussion and Recommendations}

The evaluation process of country investment potential FDI inflows could be affected by various determinants, related to actual macroeconomic data, and to current economic and business cycles in the domestic economy and cross-board ones. This study revealed a new approach for country investment potential evaluation by detaching a trend component of FDI inflows time series using the univariate methodology of decomposing performed by Hodrick-Prescott filter. The results of extraction a trend component could be used in more precise investment potential evaluations and forecasting net FDI inflows within the following time series. The repeated structural shocks and continuous fluctuation in the GDP and FDI series for Ukraine reasonably reduces the efficacy of using the H-P filter. It is fair to mention, that it was not found a statistical method of evaluation macroeconomic processes which provides undisputed results of macroeconomic processes estimation within such conditions. The process of country investment potential evaluation in conditions of political instability and macroeconomic shocks needs constant improvement, so it is important to develop more efficient approaches to perform that assessment.

Funding: This research received no external funding.

Author Contributions: conceptualization, B. Moskalenko.; methodology, B. Moskalenko.; validation, P. Mitev.; formal analysis, B. Moskalenko.; investigation, B. Moskalenko.; resources, P. Mitev; data curation, P. Mitev; writing - original draft preparation, B. Moskalenko; writing -review and editing, B. Moskalenko; visualization, P. Mitev; supervision, P. Mitev.; project administration, P. Mitev.

\section{References}

1. Armeanu, D., Crețan, G., Lache, L., \& Mitroi, M. (2015). Estimating Potential GDP for the Romanian Economy and Assessing the Sustainability of Economic Growth: A Multivariate Filter Approach. Sustainability, 7(3), https://doi.org/10.3390/su7033338

2. Badar, N., Badar, M., Malik, W., S. (2015). Measuring Business Cycle and Inflation Forecast: The Case of Pakistan. Research Journal of Finance and Accounting, 6(9), 2015, 22-34. Retrieved from: https://www.iiste.org/Journals/index.php/RJFA/article/download/22152/23351

3. Baxter, Marianne and Robert King (1999). Measuring Business Cycles: Approximate Band-Pass Filters for Economic Time Series, Review of Economics and Statistics, 4 (81), 573-593. Retrieved from: http://people.bu.edu/mbaxter/papers/mbc.pdf

4. Bjornland, Hilde C., et al. The output gap in Norway--a comparison of different methods. Economic Bulletin, 76(2), 90. Retrieved from: https://www.norges-bank.no/globalassets/upload/publikasjoner/ economic bulletin/2005-02/jore.pdf

5. Chagny O. and J. Döpke (2001). Measures of the Output Gap in the Euro-Zone: An Empirical Assessment of Selected Methods", Kiel Working Paper, 1053, Kiel Institute of World Economics. Retrieved from: https://ideas.repec.org/p/zbw/ifwkwp/1053.html

6. Chuang, A. (1991). Time Series Analysis: Univariate and Multivariate Methods. Technometrics, 33(1), 108-109. doi:10.1080/00401706.1991.10484777 
7. Chui, C.K.; Chen, G. (2009). Kalman Filtering with Real-Time Applications; Springer: Berlin, Germany. Retrieved from: https://www.springer.com/gp/book/9783642099663

8. Cotis, J., Elmeskov, J. and Mourougane, A. (2008). Estimates of Potential Output: Benefits and Pitfalls from a Policy Perspective, mimeo, OECD Economics Department. Retrieved from: http://www.oecd.org/economy/growth/23527966.pdf

9. De Masi, P.R. (1997). IMF Estimates of Potential Output: Theory and Practice; IMF Working Paper 97/177; International Monetary Fund: Washington, DC, USA. Retrieved from: https:/www.imf.org/external/pubs/ft/wp/wp97177.pdf

10. Dimitz, Maria A. (2001). Output-gaps and technological progress in European Monetary Union, Discussion Paper 20-2001, Bank of Finland. Retrieved from: https://www.ssrn.com/abstract=315484

11. Harvey, A. C. and Jaeger, A. (1993). Detrending, Stylized Facts and the Business Cycle, Journal of Applied Econometrics, John Wiley \& Sons, Ltd., 8(3), 231-47, July-Sept. Retrieved from: https://citeseerx.ist.psu.edu/viewdoc/download?doi=10.1.1.476.3906\&rep=rep1\&type=pdf

12. International Monetary Fund (IMF). (2009). Global Prospects and Policies, World Economic Outlook; IMF: Washington, DC, USA. Retrieved from: https://www.imf.org/external/pubs/ft/weo/2009/ update/01/\#: :text=The\%20world\%20economy\%20is\%20facing,view\%3A\%20Data\%20Figure\%201)

13. Jahan S., and Mahmud, A. (2013). What Is the Output Gap? Finance \& development, September 2013, 50(3). Retrieved from: https://www.imf.org/external/pubs/ft/fandd/2013/09/basics.htm

14. Kalman, R.E.; Bucy, R.S. (1961). New results in linear filtering and prediction theory. J. Basic Eng., 83, 95-108. Retrieved from: https://asmedigitalcollection.asme.org/fluidsengineering/article/83/1/95/ 426820/NewResults-in-Linear-Filtering-and-Prediction

15. Kubatko, O. V., Pimonenko, T. V. (2015). DCFTA implementation in condition of macroeconomic fluctuations in Ukraine. Mechanism of economic regulation, 4., 15-19. Retrieved from: https://essuir.sumdu.edu.ua/bitstream/123456789/69028/3/Pimonenko_Chortok_Luilev.pdf

16. Kubatko, O. V., Melnyk, L. G., Pysarenko, S. M. (2014). The impact of foreign direct investment on economic growth: case of post communism transition economies. Problems and perspectives in Management. 12(1), 17-24. Retrieved from: https:/businessperspectives.org/images/pdf/applications/publishing/templates/ article/ assets/5575/PPM 2014_1 Melnyk.pdf

17. Ladiray D., G.L. Mazzi \& F. Sartori (2003). Statistical methods for potential output estimation and cycle extraction, Eurostat. Retrieved from: https://ec.europa.eu/eurostat/documents/3888793/5815765/KS-AN-03-015EN.PDF/19128aef-fe5c-47ea-b7a1-c1f6a412258e

18. Laxton, D.; Tetlow, R. (1992). A Simple Multivariate Filter for the Measurement of Potential Output; Technical Report, 59; Bank of Canada: Ottawa, ON. Retrieved from: https://ec.europa.eu/eurostat/documents/3888793/5815765/KS-AN-03-015-EN.PDF/19128aef-fe5c-47ea-b7a1c1f6a412258e

19. Murasawa, Y. (2015). The multivariate Beveridge-Nelson decomposition with $\mathrm{I}(1)$ and $\mathrm{I}(2)$ series. Economics Letters, 137, 157-162. doi:10.1016/j.econlet.2015.11.001

20. Nelson, E.; Nikolov, K. (2003). UK inflation in the 1970s and 1980s: The role of output gap mismeasurement. J. Econ. Bus. 2003, 55, 353-370. Retrieved from: https://ideas.repec.org/a/eee/ jebusi/ v55y2003i4p353-370.html

21. Okun, A.M. (1962). Potential GNP: Its Measurement and Significance; Cowles Foundation Paper 190. Cowles Foundation, Yale University: New Haven, CT, USA. Retrieved from: https://cowles.yale.edu/author/arthur$\underline{\text { m-okun }}$

22. Orphanides, A.; van Norden, S. (2002). The unreliability of output-gap estimates in real time. Rev. Econ. Stat. 2002, 84, 569-583.

23. World Bank (2020). World Development Indicators 2019. World Bank. Retrieved from https://data.worldbank.org/indicator. 